\title{
Failure of translocated, captive-bred North Island Weka Gallirallus australis greyi to establish a new population
}

\author{
GARY N. BRAMLEY and CLARE J. VELTMAN
}

\begin{abstract}
Summary
Since 1960107 translocations of wild-caught Weka (genus Gallirallus) have occurred in New Zealand. Only four of these Weka liberations resulted in a population that persisted for more than 10 years and only one was successful on the North Island (the resultant population is now believed extinct). The reason for these failures was not known. In 1991 members of the Royal Forest and Bird Protection Society commenced breeding North Island Weka Gallirallus australis greyi in captivity for another liberation. Between 1992 and 1996101 weka were released. We used radio telemetry to follow the fates of the first 17 Weka released in the Karangahake Gorge, near Paeroa, North Island, New Zealand to determine possible outcomes of the liberation. Only one of the 17 birds released survived until 242 days post release. Most newly released Weka were killed by predators, mainly dogs. Future Weka and flightless rail introductions should occur only in areas where predators are being removed to allow survival of released birds and production of young to exceed mortality.
\end{abstract}

\section{Introduction}

The North Island Weka Gallirallus australis greyi was once found throughout the North Island of New Zealand. Weka populations are now limited to the East Cape region where they are scattered and at a low density (Bramley 1996, Beauchamp 1997). Some Weka populations are still declining in numbers (Bramley 1996, G. N. Bramley unpubl. data). North Island Weka are also found on three small islands: Kawau Island, Rakitu (Arid) Island and Mokoia Island in Lake Rotorua (Figure 1). An earlier Weka population disappeared from Kawau Island by 1923 (A. J. Beauchamp, in litt. 1997), but were then reintroduced and the number of Weka on Mokoia Island fluctuates (Graeme 1994). Weka are considered to be under an "actual or potential threat of extinction" because of their low numbers and restricted distribution (Molloy and Davis 1992). Flightless rails are generally prone to extinction (Olson 1989) and we can find only two studies addressing ways of increasing rail numbers (Miller and Mulette 1985, Bramley 1996).

All three Weka populations on small islands were the result of translocations, and 107 translocations of wild-caught birds occurred between 1960 and 1988 (C. Ward in litt. 1992). One other translocation (of 149 birds released in five liberations) was successful in establishing a population on the North Island, at 


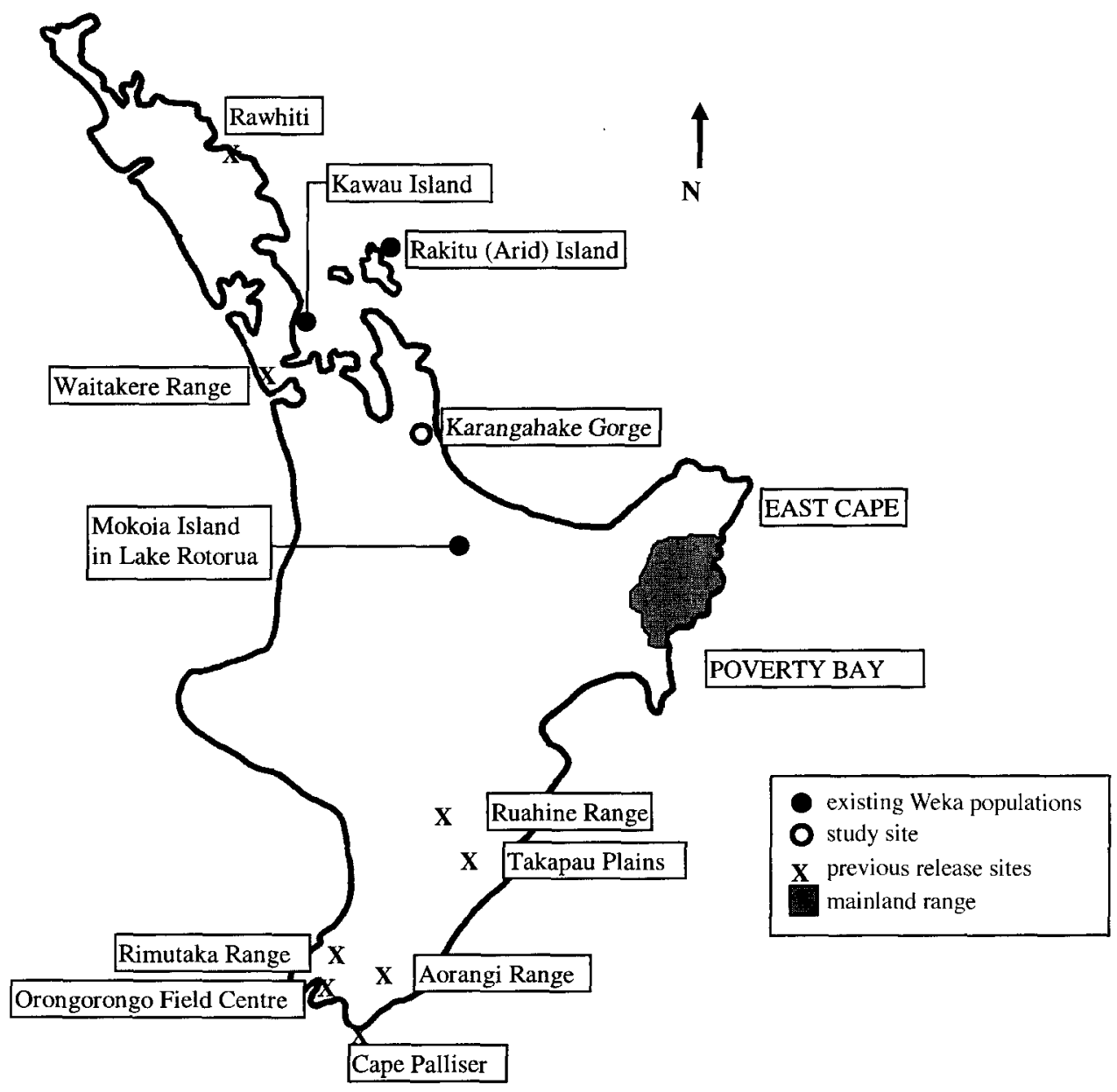

Figure 1. Locations of selected previous Weka releases and all extant Weka populations on or near the North Island of New Zealand.

Rawhiti (Robertson 1976), but that population is probably now extinct (A. J. Beauchamp, pers. comm. 1996). These translocations took place when Weka were common in the Poverty Bay region and most aimed primarily to reduce localized Weka damage to private and commercial gardens with the re-establishment of Weka populations as a secondary aim (C. Ward in litt. 1992). The results of only a few of these translocations have been published (Pracy 1969, Robertson 1976, MacMillan 1990). The reason for the decline in Weka numbers and their failure to recover is not known but is likely to be due to more than one cause (Bramley 1996, Beauchamp 1997, G. N. Bramley, unpubl. data).

The following conditions could be expected to contribute to population persistence after a translocation: a large number of founders, a high intrinsic rate of increase with low variance, a minimal effect of predators and competitors (Shaffer 1987, Griffith et al. 1989, MacMillan 1990), a low frequency of environmental catastrophes (e.g. droughts or floods, Shaffer 1987) and a large number 
of releases and many release sites (Veltman et al. 1996). Weka have been released many times at many diverse sites including Rawhiti, the Waitakere Ranges, the north-eastern Ruahines, Palliser Bay, Orongorongo Valley and the Takapau Plains (Figure 1). Weka pairs are capable of rearing four clutches of four young in a year (Carroll 1963a, G. N. Bramley unpubl. data). They are omnivorous and some unsuccessful releases have used relatively large numbers of birds, for example MacMillan (1990) reports the release of 139 Weka in the Waitakere Ranges. Pracy (1969) considered that the small number of founders was "likely" to have contributed to the failure of a release of 13 birds, in 1958, at the Rimutaka Ranges near Wellington. MacMillan (1990) suggested that predators may have prevented Weka from establishing in the Waitakere Ranges. Graeme (1994) speculated that other releases had failed because Weka dispersed and attempted to return to their natal area.

The Royal Forest and Bird Protection Society (RFBPS), a non-governmental conservation lobby organization, announced a captive breeding programme to aid North Island Weka conservation in 1991 (Graeme 1991). The RFBPS aimed to breed Weka in captivity and release young birds to establish a new population at the Karangahake Gorge near Paeroa, North Island (Figure 1). The Karangahake Gorge was chosen as a release site for Weka prior to our involvement because Weka could disperse to dry or wet climatic zones, it appeared to have suitable habitat (e.g. in terms of food species and nesting sites) and was within the former range of the North Island Weka. Volunteer Weka breeders lived in the area and were able to accumulate Weka in the area and release them. Karangahake village and its surrounding area are visited by many tourists, something that was seen as favourable for publicizing the plight of Weka and RFBPS's attempts to assist their recovery. (A. Graeme, pers comm. 1993, A. J. Beauchamp, in litt. 1997).

Given the past failure of Weka translocations and their now threatened status, it is important to know why any translocations of Weka succeed or fail, and documentation of all such attempts is therefore vital to prevent wildlife managers from repeating previous mistakes (Short et al. 1992). Because of the (at least initially) small number of propagules and the large part that chance may play during establishment it is necessary to follow and record individual fates. To do this for Weka released by the RFBPS at Karangahake, we used radio telemetry. We expected that reliable knowledge of each Weka's fate would indicate why the translocation succeeded or failed.

\section{Methods}

\section{RFBPS preparation of Weka for release}

By 199217 birds had been successfully reared for release. Weka were reared from parental stock that came from Kawau Island and a bird-rearing facility (Otorohanga Kiwi House) by members of RFBPS who volunteered their time and facilities. The Kawau population and the captive birds were descended from Weka taken from the East Cape region when Weka numbers were high. The "soft" release procedure was decided on before our involvement and was based on the only documented successful release of Weka on the mainland, near Rawhiti (Robertson, 1976). 
Weka released at Karangahake were parent-reared in aviaries. Six of the males were over a year old when transferred to the release aviary, being 1991 offspring from Weka pairs at Otorohanga Kiwi House. The remainder were from 6 to 18 weeks of age on arrival. The average age of these birds at release was 17 weeks (S.D. $=4$ weeks, $n=11$ ). All Weka were released in groups of $2-6$ birds after spending time in an aviary at the release site. Releases were timed to coincide with our visits and to free up aviary space for incoming Weka. Weka had spent, on average, eight weeks in the aviary (S.D. $=3$ weeks, $n=17$ ). Immediately prior to their release, birds were weighed and sexed using standard morphometric measurements (Carroll $1963 b$ ). Weka were released by opening trap doors in the aviary, allowing them to wander out at will. Of the 17 birds released at Karangahake in 1992, four of them were females and 13 were males. All Weka were banded with one numbered metal band (NZ Banding Service) and at least one coloured plastic band. Supplementary food (Hilay pellets, NRM Livestock Feeds, Takanini, Auckland, NZ) was available after liberation until the end of the study.

Ten of the Weka had a radio-transmitter fitted (four females and six males). We used back-mounted two-stage VHF transmitters set at 40 pulses per minute and weighing an average of $19.3 \mathrm{~g}$. The transmitters had a 10-month battery cell and had external whip-type aerials (Sirtrack Telemetry Electronics, Havelock North, NZ). The radio transmission was set at intervals between 160 and $162 \mathrm{MHz}$. Weka carried radios on their back much like a human might wear a back-pack and they were held in place by nylon cord secured by fishing crimps. A "weak link" of cotton in the nylon loops meant that birds could free themselves if snagged. Four Weka without radios were released in October 1992. Three radio-carrying birds and three more without radios were released on 30 November 1992 and two radio-carrying birds were released on 6 January 1993. The final five Weka carrying transmitters were released on 25 March 1993. The position of all radio-carrying Weka was checked at 12-hour intervals for two days after release and then at randomly chosen times of the day during our visits until their death. Because of the way observational data collection was randomized, some Weka were checked more than once a day and others were checked less frequently. Signals from the radio-transmitters were tracked using a TR-4 receiver (Telonics Telemetry Electronics Consultants, Mesa, Arizona, U.S.A.) combined with a hand-held 3-element Yagi antenna.

\section{Radio survival}

Visits were made to Karangahake monthly from November 1992 until June 1993, except during February 1993. We spent from four to seven days in the area each month. In our absence the aviary manager (Mr G. Staples) checked bird locations opportunistically and had dead birds returned to him. We followed Weka for up to one hour, and only the point at which they were first found was used as an independent point location. We also checked the location of all Weka at least twice each trip to make sure they were still alive and carrying their radios, and noted their point locations at that time. The individual fates of radio-carrying Weka were recorded by finding dead Weka, having corpses returned to us or the aviary manager, recovery of slipped radios (fate unknown), or by the Weka still being alive at 24 June 1993 or our seeing the bird after recovery of the radio 
(recorded as alive). On I April 1993 the aviary manager discovered a female Weka being pursued by a dog, so he recaptured her and the four other Weka released with her on the 25 March 1993. Two of these birds were released again on the 11 April 1993: one was killed by a dog on 12 April, and the other by a ferret in June. The other two remained in the aviary recovering from an avian pox infection and were released again in early May. Survival estimates for these birds do not include time spent in the aviary. Radio survival refers to the length of time a Weka wore a radio and was used as a measure of Weka survival.

Survival of radio-carrying birds and birds without radios (measured by sightings) was examined at Karangahake by log-transforming the survival estimate (in days) and then comparing the two samples using a $t$-test.

\section{Measures of dispersal and home range size}

Dispersal was estimated by calculating the maximum straight-line distance of sightings of unradioed birds $(n=2)$ or point locations of radio-carrying Weka. One unradioed Weka was recovered dead, the other was the longest surviving bird and was seen regularly. We also calculated the home range area from the point locations using the minimum convex polygon method (Hough 1982).

\section{Results}

\section{Radio survival and Weka home ranges}

Few point locations were gained from Weka at Karangahake (range 5-24 per bird) because radio survival was low (median $=13$ days, range $=2-128$ days, $n=$ 10). This can be accounted for by the ultimate fate of the Weka: seven were killed by dogs, one by a ferret Mustela putorious, one died of unknown causes and the fate of one was unknown. No radio-carrying Weka were known to be alive after 24 June 1993.

At least five of the incidences of dog predation were by one dog whose owner discovered the Weka and returned them to the aviary manager. Weka were killed when they ventured into a damp swampy area immediately around the dog owner's property. A second dog killed at least one Weka. These are necessarily minimum estimates because in some other cases the predator was not able to be identified. Weka were generally killed soon after their release (Figure 2). Newly released Weka carrying radios disappeared no more quickly than Weka not carrying radios (Two-sample $t$-test on log-transformed data, $t=0.13, P=0.90, d f=$ 5). Radio-carrying Weka also had small home ranges (median $=1.56$ ha, mean $=$ $2.68 \mathrm{ha}$, S.D. $=2.91 \mathrm{ha}$ ).

\section{Weka dispersal}

Weka had dispersed no more than $100 \mathrm{~m}$ within the first 48 hours after release. By the end of the study they had dispersed up to $10 \mathrm{~km}$ (mean $=1269 \mathrm{~m}$ S.D. $2840 \mathrm{~m}$ median $=228 \mathrm{~m}$ range $134-10$ ooo $\mathrm{m}$ ). The Weka home ranges were long and thin and grouped around the release site. Only one or possibly two Weka had dispersed so far that they could be considered lost from the potential 


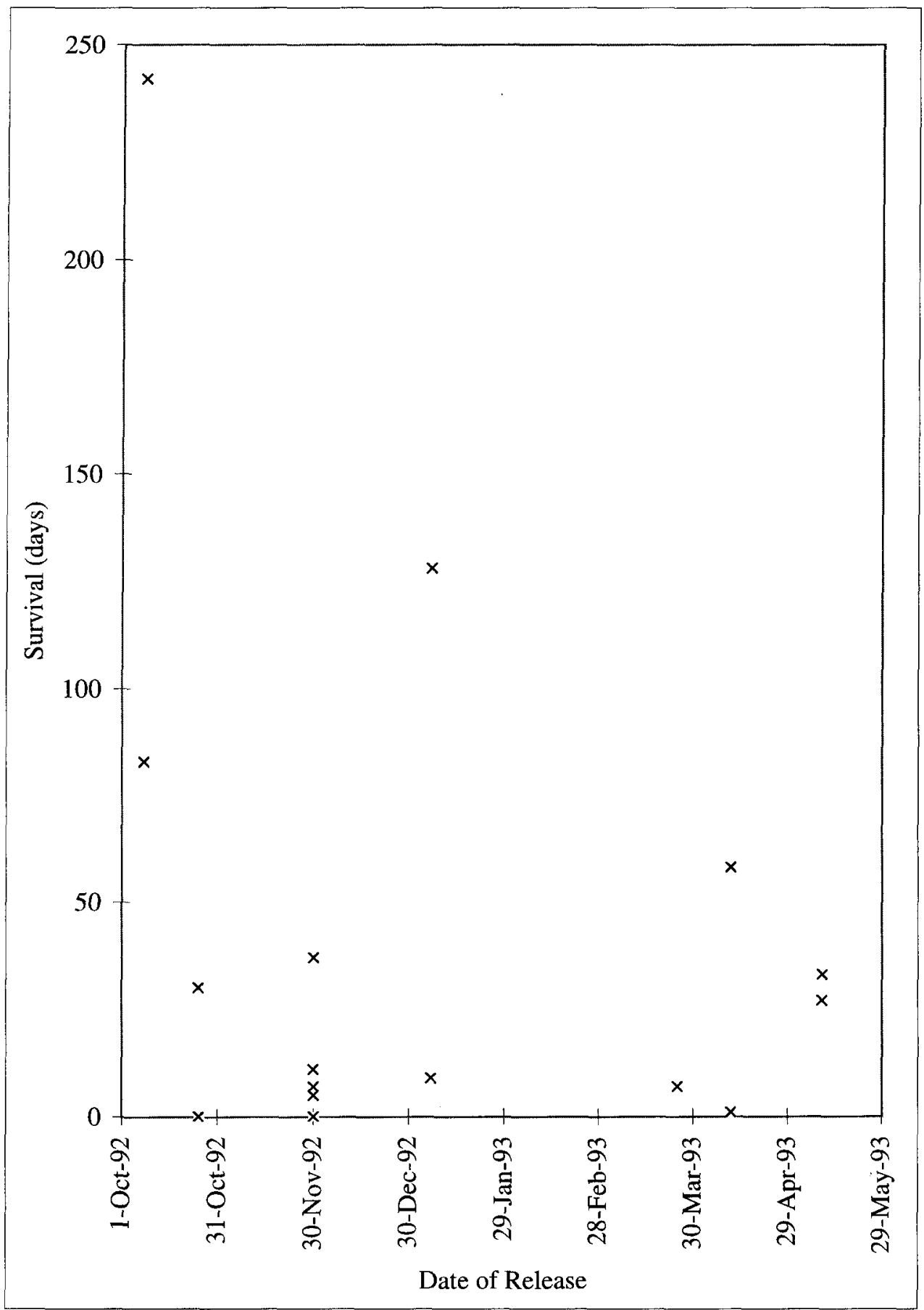

Figure 2. Survival (in days) of newly released Weka at Karangahake Gorge. Weka released in April and May 1993 were birds initially released on 25 March 1993, but returned to the aviary to protect them from a dog (see text). The survival estimate does not include time spent in captivity, but does include all days they were not in an aviary. 
pool of breeders around the aviary. One of these birds, an older male not fitted with a radio, was collected dead from the roadside $10 \mathrm{~km}$ from the aviary. The other, a female carrying a radio, was released in March and stayed around the aviary until mid-April. In mid-April most of her cohort were dead (although there were still Weka in the aviaries) and she then moved about $4 \mathrm{~km}$, where she appeared to settle and was later killed.

\section{Discussion}

Weka released at Karangahake used small areas and experienced extremely low survival. Home range estimates from such a small number of fixes probably do not adequately reflect home range size of permanently resident Weka. Weka used areas that were long and thin, not because suitable habitat patches were long and thin, but perhaps because the Weka were still exploring the area, more or less in a straight line, when they were killed. Pracy (1969) reported that dispersal from liberation sites in the Rimutaka and Aorangi Ranges was "limited" with the largest dispersal being five miles $(8.05 \mathrm{~km})$ although Weka dispersed up to $18 \mathrm{~km}$ from their release site at Huia in the Waitakere Ranges (MacMillan 1990). It may be that dispersal is slow as Weka gain local knowledge. Only two Weka could be deemed "lost" from the release site as a result of their dispersal. The birds failed to establish a new population at Karangahake because of predation: only one $(6 \%)$ of the 17 birds released there survived until the end of this study. This is the first time the reason for a failure of a release of translocated Weka has been known.

Other rail populations have been threatened by predators (Ripley 1977, Jenkins 1979, Miller and Mulette 1985, Olson 1989, Bramley 1996) yet the risk of predation on small Weka populations was considered low by RFBPS (Graeme 1991, 1994). RFBPS continued to release Weka between October 1992 and March 1996 after the removal of the dog that killed five of the Weka we studied. One hundred and one Weka were released in total. Although there were as many as 26 Weka alive at one time and breeding did occur (G. and E. Staples, pers. comm. 1995, in litt.1996) the release was abandoned in 1996 after ferrets killed the remaining Weka. Weka at Rakauroa (East Cape) were at risk of predation by cats and ferrets (Bramley 1996) but none of 21 radio-carrying birds were killed by dogs during a two-year study (Bramley 1996, G. N. Bramley unpubl. data). Weka in both areas used parts of their home range that provided them with cover and made them difficult to observe (G. N. Bramley unpubl. data). Predation has prevented establishment of other captive reared birds (e.g. Cheer Pheasant Catreus wallichii, (Garson et al. 1992), Hawaiian Goose or Nene Branta sandvicensis, (Black and Banko 1994), Mallee-fowl Leipoa ocellata (Priddell and Wheeler 1994), and the Hawaiian Crow Corvus hawaiiensis (Kuehler et al. 1995)). Translocations of wildcaught animals have also failed for this reason, e.g. macropod marsupials (Short et al. 1992) and ringtail possums Pseudocheirus peregrinus (Augee et al. 1996).

Carrying a radio can reduce survival of at least some species (Burger $e t$ al. 1991) but did not appear to hinder Weka survivorship at Karangahake; radioed and unradioed Wekas disappeared at a similar rate.

Scott and Carpenter (1987) state "Because of the high costs associated with release programs and the endangered status of many of the animals we can 
not afford to introduce new individuals to new environments without a high probability of their surviving and contributing genetically to a wild population". The release of Weka at Karangahake was a failure from Scott and Carpenter's point of view: not only did birds have a negligible chance of survival, but were they to persist it is most unlikely they would ever expand their range enough for it to be contiguous with current Weka range. A New Zealand Department of Conservation permit required to conduct this release specifically excluded RFBPS from releasing Weka in areas where they could be expected to come in contact with wild Weka to prevent transmission of avian diseases. Adequate screening of bird health prior to release would remove this obstacle (S. Fancy, in litt. 1997). Some Weka populations have a male-biased sex ratio (G. N. Bramley unpubl. data) and release of captive bred Weka, particularly females, into an existing population should be seriously considered, particularly if predator removal is done at the same time. The aim of the RFBPS programme was to establish a Weka population that acted as a source from which Weka could move into other (sink) areas, i.e. to develop a metapopulation. Given this aim Weka should be released in an area where productivity could be higher than in most present mainland areas, and high enough to produce excess juveniles able to disperse to establish or augment other populations. This aim could also be achieved by releasing birds in or near existing populations.

Captive breeding of the Lord Howe Island Woodhen Tricholimnas sylvestris for release into pig-free areas resulted in an increase in the population size and range of the Woodhen (Miller and Mulette 1985). This is a case where the limiting factor was identified and mitigated with the expected result (Caughley 1994). We do not know what the limiting factors of scattered and low-density Weka populations are, and identifying them will be difficult, but it seems likely that predators have an effect (Bramley 1996, this study). MacMillan (1990) was the first to recommend that Weka be released into predator-proofed areas and on the basis of our study it seems imperative that only areas with a low predator density be considered for future releases.

Griffith et al. (1989) found that translocations of wild-caught animals were generally more successful $(75 \%)$ than those from captive-bred stock $(38 \%)$. One potential reason for this difference in persistence is that captive-reared animals are often naive in their behaviour towards predators (Garson et al. 1992, Marshall and Black 1992, Augee et al. 1996). Maloney and McLean (1995) were able to teach New Zealand Robins Petroica australis unfamiliar with predators to show more anti-predator behaviours. Although Maloney and McLean did not investigate whether more anti-predator responses resulted in better survival, this training technique could be tried with Weka. The breeding of rare species in captivity has potential for aiding species recovery via reintroductions (Mallinson 1995), but the success of reintroduction programmes for captive-reared species is variable. A systematic approach is needed to isolate factors affecting Weka survival in predator-free areas (Sarrazin and Barbault 1996). S. Fancy (in litt. 1997) has found that captive-reared Hawaiian Solitaires Myadestes obscurus showed greater site fidelity after translocation to predator-managed areas than wild-caught birds. We suggest that a systematic approach to Weka releases should compare the survival and site fidelity of captive-reared and wild-caught Weka. Other factors to be tested include birds trained to recognize predators versus untrained birds, 
juvenile versus mature birds, hard versus soft release and releases of single birds, pairs or groups of birds. The recent release of 29 captive-bred Weka on Pakatoa Island in the Hauraki Gulf (Graeme 1996) will help identify other limiting factors affecting Weka populations because no ferrets or stoats Mustela erminea occur there. This island population and the improving techniques of captive propagation developed by RFBPS (for example, 52 young were reared between March 1994 and March 1995 and 48 in 1995-96 compared with 17 in the first year of the programme (G. and E. Staples in litt. 1996)) are helping to reduce the likelihood of Weka extinction.

\section{Acknowledgements}

This study was funded in part by a summer field grant from the Waikato Branch of the RFBPS and by a grant from the J. S. Watson Conservation Trust. The Department of Ecology, Massey University also contributed. The authors wish to thank Dr Tony Beauchamp who gave advice and commented on an earlier draft of this paper, Dr Steve Fancy who made available his unpublished data, Ann and Basil Graeme who co-ordinated the programme, Gary and Elaine Staples and the members of the captive breeding group. This manuscript was improved by comments from Joe Waas, John Innes and an anonymous reviewer. Catherine Beard drew the map.

\section{References}

Augee, M. L., Smith, B. and Rose, S. (1996) Survival of wild and hand-reared Ringtail possums (Pseudocheirus peregrinus) in bushland near Sydney. Wildl. Res. 23: 99-108.

Beauchamp, A. J. (1977) The decline of the North Island Weka (Gallirallus australis greyi) in the East Cape and Opotiki Regions, North Island, New Zealand. Notorris 44: 27-35.

Black, J. M. and Banko, P. C. (1994) Is the Hawaiian goose (Branta sandvicensis) saved from extinction? Pp. 394-410 in P. J. S. Olney, G. M. Mace and A. T. C. Feistner, eds. Creative conservation: interactive management of wild and captive animals. London: Chapman \& Hall.

Bramley, G. N. (1996) A small predator removal experiment to protect North Island Weka (Gallirallus australis greyi) and the case for single-subject approaches in determining agents of decline. N. Z. J. Ecol. 20: 37-43.

Burger, L. W., Ryan, M. R., Jones, D. P. and Wywialowski, A. P. (1991) Radio transmitters bias estimates of movements and survival. J. Wildl. Man. 55: 693-697.

Carroll, A. L. K. (1963a) Food habits of the North Island Weka. Notornis 10: 289-300.

Carroll, A. L. K. (1963b) Sexing of wekas. Notornis 10: 302-303.

Caughley, G. (1994) Directions in conservation biology. J. Anim. Ecol. 63: 215-244.

Garson, P. J., Young, L. and Kaul, R. (1992) Ecology and conservation of the Cheer Pheasant Catreus wallichii. Studies in the wild and the progress of a reintroduction project. Biol. Conserv. 59: 25-35.

Graeme, A. (1991) The mystery of the vanishing weka. Forest and Bird 259: 14-15.

Graeme, A. (1994) Return of the weka. Forest and Bird 272: 10-17.

Graeme, A. (1996) Golf balls main threat to weka. Forest and Bird 281: 6.

Griffith, B., Scott, M. J., Carpenter, J. W. and Reed, C. (1989) Translocation as a species conservation tool: status and strategy. Science 245: 477-480.

Hough, N. (1982) Determining range area from location data. Biotelem. Patient Monit. 9: 10-17.

Jenkins, J. M. (1979) Natural history of the Guam Rail. Condor 81: 404-408 
Kuehler, C., Harrity, P., Lieberman, A. and Kuhn, M. (1995) Reintroduction of hand-reared alala Corvus hawaiiensis in Hawaii. Oryx 29(4): 261-266.

MacMillan, B. W. H. (1990) Attempts to re-establish Wekas, Brown Kiwis and Redcrowned Parakeets in the Waitakere Ranges. 'Notornis 37: 45-51.

Mallinson, J. J. C. (1995) Conservation breeding programmes: an important ingredient for species survival. Biodiv. Conserv. 4: 617-635.

Maloney, R. F. and McLean, I. G. (1995) Historical and experimental learned predator recognition in free-living New Zealand robins. Anim. Behav. 50: 1193-1201.

Marshall, A. P. and Black, J. M. (1992) The effect of rearing on subsequent behavioural traits in Hawaiian Geese (Branta sandvicensis): implications for the recovery programme. Bird Conserv. Int. 2: 131-147.

Miller, B. and Mulette, K. J. (1985) Rehabilitation of an endangered Australian bird: the Lord Howe Island Woodhen Tricholimnas sylvestris (Sclater). Biol. Consero. 34: 55-95.

Molloy, J. and Davis, A. (1992) Setting priorities for the conservation of New Zealand's threatened plants and animals. Wellington, New Zealand: Department of Conservation.

Olson, S. L.(1989) Extinction on islands: man as a catastrophe. Pp. 50-53 in D. Western and M. Pearl, eds. Conservation for the twenty-first century. New York: Oxford University Press.

Pracy, L. T. (1969) Weka liberations in the Palliser Bay region. Notornis 16: 212-213.

Priddell, D. and Wheeler, R. (1994) Mortality of captive-raised Malleefowl Leipoa ocellata, released into a Mallee remnant within the wheat-belt of New South Wales. Wildl. Res. 21: $543-552$.

Ripley, S. D. (1977) Rails of the world: a monograph of the family Rallidae. Boston: David R. Godine.

Robertson, D. B. (1976) Weka liberation in Northland. Notornis 23: 213-219.

Sarrazin, F. and Barbault, R. (1996) Reintroduction: challenges and lessons for basic ecology. TREE 11: $474-478$.

Scott, J. M. and Carpenter, J. W. (1987) Release of captive-reared or translocated endangered birds: what do we need to know? Auk 104: 544-545.

Shaffer, M. (1987) Minimum viable populations: coping with uncertainty. Pp. $69-86$ in M. E. Soule, ed. Viable populations for conservation. Cambridge, U.K.: Cambridge University Press.

Short, J., Bradshaw, S. D., Giles, J., Prince, R. I. T. and Wilson, G. R. (1992) Reintroduction of macropods (Marsupalia: Macropodoidea) in Australia: a review. Biol. Conserv. 62: 189-204.

Veltman, C. J., Nee, S. and Crawley, M. J. (1996) Correlates of introduction success in exotic New Zealand birds. Amer. Nat. 147: 542-557.

GARY N. BRAMLEY ${ }^{1}$ AND CLARE J. VELTMAN ${ }^{2}$

Department of Ecology, Massey University, Private Bag 11-222, Palmerston North, New Zealand

( ${ }^{1}$ Now at Department of Biological Sciences, University of Waikato, Private Bag 3105, Hamilton, New Zealand. ${ }^{2}$ Now at Science and Research Division, Department of Conservation, P.O. Box 10-420, Wellington, New Zealand.) 